\title{
RECREATIONAL SUSTAINABILITY OF BOG PLANT COMMUNITIES IN POLISTOVSKY STATE NATURE RESERVE (RUSSIA)
}

\author{
Ekaterina O. Korolkova ${ }^{1,2}$, Anna V. Mironova ${ }^{3}$ \\ ${ }^{1}$ National Research University Higher School of Economics, Russia \\ ${ }^{2}$ Moscow Pedagogical State University, Russia \\ e-mail:korol-k@mail.ru \\ ${ }^{3}$ Institute of Biology of Karelian Research Centre RAS, Russia \\ e-mail:shen-ku@bk.ru
}

Received: 12.04.2019. Revised: 02.10.2019. Accepted: 17.10.2019.

\begin{abstract}
The definition of recreational sustainability in bogs is becoming an urgent task in Russia as a result of ecological tourism developed in Protected Areas. In this study, we assessed the impact of recreational nature management on wetland plant communities of the Plavnitskoye Boloto ecological path in the Polistovsky State Nature Reserve solving the following tasks: 1) to determine the threshold of permissible anthropogenic impact on wetland sites with different types of plant communities; 2) to evaluate the recovery of vegetation cover; 3 ) to determine the relative tolerance of bog plant communities to trampling. Modelling of the direct anthropogenic impact on bog plant communities with different load values has made it possible to assess the damage on the vegetation cover visually and to reveal their resistance and ability to subsequent recover. We demonstrated that the Phragmites-Sphagnum community (Phragmites australis + Eriophorum vaginatum - Sphagnum fallax + Sphagnum angustifolium) was the least resistant to trampling, while the shrub-Carex-Sphagnum plant community (Chamaedaphne calyculata + Oxycoccus palustris + Menyanthes trifoliata + Eriophorum vaginatum - Sphagnum fallax) was the most resistant. After the removal of anthropogenic load on the studied sites, the damaged vegetation cover recovered to different degrees. In the first year, the plant communities of the shrubCarex-Sphagnum bog had the fastest recovery, where relatively hygrophilous species of Sphagnum mosses predominate under mesotrophic conditions and a higher level of groundwater. The Eriophorum-Sphagnum community (Pinus sylvestris (f. willkomii) - Andromeda polifolia + Oxycoccus palustris + Eriophorum vaginatum + Rhynchospora alba - Sphagnum magellanicum) had the best long-term resilience for three years, and, as a result, it turned out to be the most tolerant to trampling. In some parts of the Phragmites-Sphagnum mesotrophic bog, the original plant community did not recover after three study years. Thus, this type of bog is the most vulnerable to recreational impact.
\end{abstract}

Key words: anthropogenic impact, ecological tourism, Protected Areas, recreation, wetland

\section{Introduction}

Bogs are unique landscapes with many useful properties, both in economic and in biosphere terms. The wetland territories of the former Soviet republics had been actively used for peat mining and irrigation engineering, undergoing active anthropogenic transformation, resulting in the loss of bogs as a component of the natural landscape. Nowadays, they have become an attractive object for tourism and educational and scientific excursions (Sirin \& Minayeva, 2001). In the European part of Russia, this kind of eco-tourism is also actively developed in several Protected Areas (Korolkova \& Shkurko, 2016a). Recreational use of wetland sites that, for one reason or another, are not equipped with boardwalks, leads to the destruction of the bog vegetation, which means violation of the nature protection regime. Wetland plant communities under the influence of regular foot traffic either die completely and peat expose, or are replaced by the invasion of alien species and species characteristic for denuded wet- land areas, where these species are not threatened by competition. The recovery of vegetation cover of damaged areas may last for years (Slater \& Agnew, 1977; Botch \& Masing, 1979).

Thus, the ecological tourism poses a theoretical and practical task of linking nature conservation with the principles of accessibility of valuable natural components. Currently, much attention is paid to sociological research, the main purpose of which is to find out the expectations of recreants for better managing of recreation (Pickering et al., 2018). However, the use of natural resources of Protected Areas in tourism should be regulated, and the framework of recreational planning, engineering and use of ecosystems should be based on scientifically determined norms of environmental loads (Chizhova, 2011).

In Russia the Polistovsky State Nature Reserve is one of the most popular places for ecological tourism on the bogs. There are four ecological routes, the most visited of which is the Plavnits- 
koye Boloto path. According to data of the Department of Environmental Education and Tourism, 402 people visited it in 2014; in 2016, this number increased up to 568 people; and, in 2018, the attendance of the Plavnitskoye Boloto path amounted to 649 people. Thus, the recreation capacity of this route needs precise determination with subsequent attendance adjustment. But this task can be completed only with the involvement of specialists from different fields, similarly to as it was done by studying the neighbouring Rdeysky State Nature Reserve by both botanists and zoologists (Korolkova et al., 2017). Authors have reported the additional limitations on the visiting period and the number of visitors on the ecological path to avoid the disturbance of birds. In addition to the recreational use of paths equipped with boardwalks, off-path hiking now exists in the Protected Area, including walking on bogshoes.

In 2018, this type of path began to operate from the island Alekseevsky. In some parts of the route a path has been formed. And 27 people walked there during the season, according to the ecotourism specialist M. Morozova. Despite their small attendance, traces are already clearly visible in the swamp. Nowadays, the consequences of walking on bogshoes, as well as the difference of its impact in comparison with hiking on the bog surface are studied in Estonia (Kose \& Tammiste, 2018).

Rationing of the recreational forest ecosystem use has been fruitfully developed for a long time both in Russia and abroad (Chizhova, 2011; Marzano \& Dandy, 2012; Hammitt et al., 2015). Cole (1995c) described an experiment for forest and meadow plant communities and justified the calculation of the average weight of an «experimental tourist» for trampling. Cole $(1995 \mathrm{a}, \mathrm{b})$ considered also the response of different vegetation types to experimental trampling and its correlation with trampling intensity, plant morphology, and site characteristics. There are only few such studies known for wetlands. In 1977-1979, one of the first studies of recreational trampling in Russian wetlands was conducted in the Leningrad region (Botch, 1981). Then a similar study was conducted in Belarus (Zelenkevich et al., 2008). The research consisted of modelling (simulation) of anthropogenic trampling with different degrees of load and subsequent measurements of the width and depth of the formed trails.

Cole $(1995 a, b)$ applied the concepts of plant vulnerability attributes as «resistance» and «resilience». Resistance is an ability of vegetation ex- posed by trampling to resist change, while resilience is an ability to recover after impact. These attributes were applied for the terrestrial plant communities, which in natural conditions tend to maintain its density and species composition. The investigated bog plant communities are mostly covered by Sphagnum mosses (80-100\%) forming a continuous mat of densely growing shoots, with minor participation of vascular plants relatively similar on each sample plot. Sphagnum shoots integrity and maintaining the smooth surface of the carpet to minimise moisture losses are the general requirements for the successful existence of bog plant communities (Mironov \& Kondratyev, 2017; Mironov et al., 2018). Therefore, in our study, we used the terms of «resistance» and «resilience» as the attributes of Sphagnum-dominated plant communities tending to the maintenance of a continuous smooth mat what in this case means the decline of width and depth parameters of tracks after trampling.

The analysis of the vegetation cover damage and regeneration was conducted by Korolkova \& Shkurko (2016b). Newer data were also reported by Korolkova \& Shkurko $(2017,2019)$.

Our study was aimed to assess the impact of recreational use on wetland plant communities of the Plavnitskoye Boloto ecological path in the Polistovsky State Nature Reserve. To accomplish the goal we set the following tasks: 1) to place sample plots in the wetland of the Plavnitskoye Boloto path in various types of bog plant communities and to simulate the anthropogenic trampling of vegetation cover on the sample plots with different intensity and to estimate the level of vegetation cover destruction; 2) to study the sample plots in the wetland of the Plavnitskoye Boloto path twice during the vegetation period (in summer and autumn) and to assess the recovery of damaged vegetation cover; 3) to compare the data of resistance and recovery of bog plant communities and determine the relative tolerance to trampling.

\section{Material and Methods}

The study area is located in the Polistovsky State Nature Reserve. This Protected Area is situated in the east of the Pskov region (Bezhanitsky district and Loknyansky district), in the western part of the Polistovo-Lovatskaya wetland system - southern part of the Priilmenskaya lowland (Fig. 1). The wetland system is a large tract of low-disturbed raised bogs placed on the northeast of the Bezhanitsky upland and to the west of the Valdai upland in the Russian Plain (Nature of Polistovsky Reserve, 2019). 


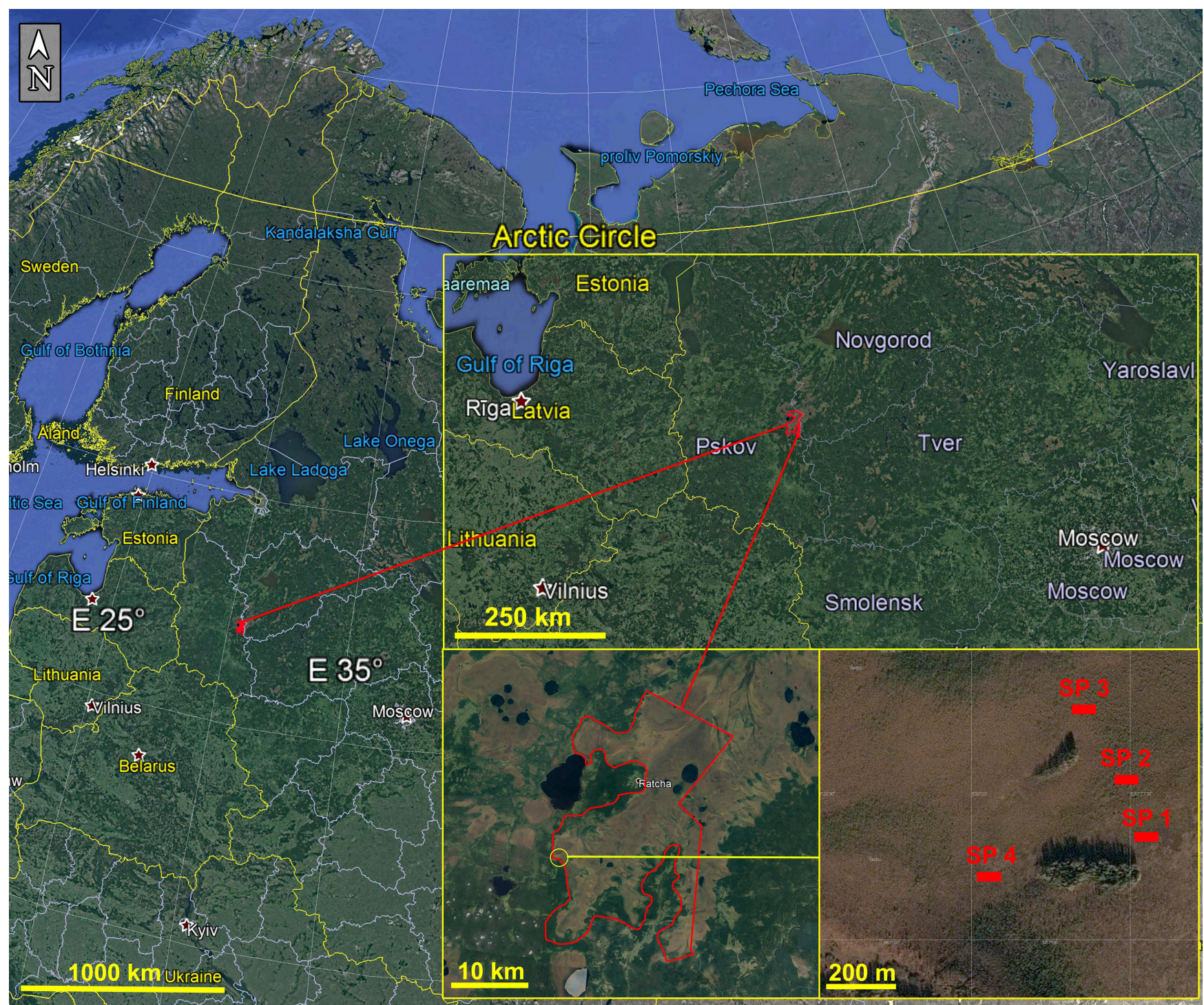

Fig. 1. The location of the Polistovsky State Nature Reserve (red outlines) and sample plots (red boxes).

In June 2016, four sample plots (SP) were established and described from the wetland parts of the Plavnitskoye Boloto ecological path. They were confined to three different types of plant communities. The description of plant community in sample plots was conducted using the Brown-Blanquet scale to determine the projective cover and abundance of species. The names of the plant communities are compiled using the order of dominants. The characteristics of bog vegetation are assigned according to the classification developed by V.A. Smagin (Komarov Botanical Institute of RAS) applying to the Polistovsky State Nature Reserve. In the latest study of the systematics of Sphagnum mosses, Hassel et al. (2018) suggested that European types of the magellanicum group should be distinguished as two species. In our article, we use the former name, Sphagnum magellanicum Brid., which we identified as the sample in 2016.
SP №1 and SP №4 placed on mesotrophic shrub-Carex-Sphagnum bog sites without a wood synfolium within the moor edge, nearby the bog mineral island. The micro-relief is flattened. The groundwater depth is $20 \mathrm{~cm}$ or less. In SP №1, the plant community is Chamaedaphne calyculata + Oxycoccus palustris + Menyanthes trifoliata + Eriophorum vaginatum - Sphagnum fallax, while in SP №4 is Betula pendula - Andromeda polifolia + Menyanthes trifoliata + Eriophorum vaginatum - Sphagnum magellanicum + Sphagnum fallax. SP №2 is a site of an oligotrophic Eriophorum-Sphagnum structured bog with pine (Pinus sylvestris L.) on the hummocks. The microrelief determined the intermittency of hummocks with pine and carpet lows with Rhynchospora alba (L.) Vahl. The groundwater depth is $10-25 \mathrm{~cm}$. The plant community is Pinus sylvestris (f. willkomii) - Andromeda polifolia + Oxycoccus palustris + Eriophorum vaginatum + Rhynchospora alba 
- Sphagnum magellanicum. SP №3 situated on Phragmites-Sphagnum mesotrophic bog without a wood synfolium and it is a flattened mesotrophic plot with small hummocks. The groundwater depth is $5-20 \mathrm{~cm}$. The plant community is Pinus sylvestris (f. willkomii) - Chamaedaphne calyculata + Phragmites australis + Eriophorum vaginatum - Sphagnum fallax + Polytrichum strictum.

The anthropogenic impact was simulated by a single-time trampling of the vegetation cover with various loads. In SP №1, SP №2, and SP №3, six tracks of $20 \mathrm{~m}$ in length were foot-trampled with the following loads: 1, 4, 6, 20, 60, 180 passes, while in SP №4, the same number of tracks was trampled with the following transitional values: 10, 30, 50, 70, 90 and 110 passes. The disturbance degree of the vegetation cover was determined by visual cover estimates. Measurements of the depth and width of the formed paths were made every $2.0 \mathrm{~m}$ throughout the track in 2016-2018 twice: in summer (June, July) and in October.

Statistical data processing was performed using the STATISTICA 10 software (Stat Soft. Inc., USA). Graphic processing was performed with GraphPad Prism (GraphPad Software, Inc., CA). The significance of arithmetic means differences of distinct bog plant communities was evaluated by the Student t-test. The obtained values are provided in the text below where $\mathrm{t}=$ calculated value and $\mathrm{t}(00.5)=$ table value.

\section{Results and Discussion}

Vegetation cover destruction

The destruction of wetland plant communities under anthropogenic impact and its recovery after four months were discussed in detail by Korolkova \& Shkurko (2016b). Here the main results are presented.

Visually it was determined that noticeable paths are formed after 20 passes in the mesotrophic shrubCarex-Sphagnum and the oligotrophic structured
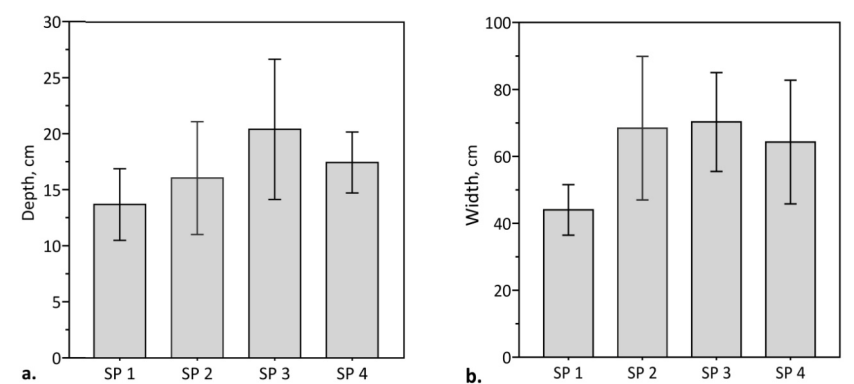

Fig 2. Depth (a) and width (b) of tracks formed at the beginning of the experiment after 60 passes (SP №1, SP №2, SP №3) or 70 passes (SP №4) in the Polistovsky State Nature Reserve during 2016-2018.
Eriophorum-Sphagnum bog plant communities. In the mesotrophic Phragmites-Sphagnum community, the pathway network is clearly visible even after four passes, while a stable path is formed after six passes. In the sample plots, the vegetation cover damage was more intensive where the groundwater level was higher and the density of Sphagnum cover was lower. Similar results were obtained by Botch (1981), Zelenkevich et al. (2008).

Results of measuring the tracks at the beginning of the experiment (Fig. 2, Fig. 3) indicate the mesotrophic shrub-Carex-Sphagnum bog site was the most resistant to damage (SP №1). The width of the path after 60 passes was $44 \pm 2.9 \mathrm{~cm}$, after 180 passes it was $54.9 \pm 3.1 \mathrm{~cm}$; the depth was $13.7 \pm$ $1.2 \mathrm{~cm}$ and $15.5 \pm 0.8 \mathrm{~cm}$ respectively. The higher resistance of SP №1 may be explained by the abundance of Menyanthes trifoliata L. with its creeping rootstocks thickening the moss cover (Botch, 1981).

The oligotrophic structured portion of the bog with Eriophorum-Sphagnum with pine on the hummocks (SP №2) has a lower resistance than the previous site. The width of the path after 20 passes was almost 2 times $\left(\mathrm{t}=5.36 ; \mathrm{t}_{(0.05)}=2.45\right)$ higher, and after 60 passes 1.5 times $\left(\mathrm{t}=2.7 ; \mathrm{t}_{(0.05)}=2.45\right)$ higher than the width of the paths of the previous section (SP №1) with the same load. However, after 180 passes, their values were similar: $59.7 \pm$ $8.5 \mathrm{~cm}$. These fluctuations can be explained by the alternating structures of the site's microrelief. The depths of the paths also exceeded those in SP №1.

The shrub-Carex-Sphagnum mesotrophic bog in SP №4 is more resistant to damage than the Eriophorum-Sphagnum bog in SP №2 until the load value does not exceed 90 passes. Under heavier loads, the situation gradually changed. Therefore, the plant community in SP №4 has an intermediate resistance rate between the shrub-Carex-Sphagnum (SP №1) and oligotrophic Eriophorum-Sphagnum (SP №2) communities.
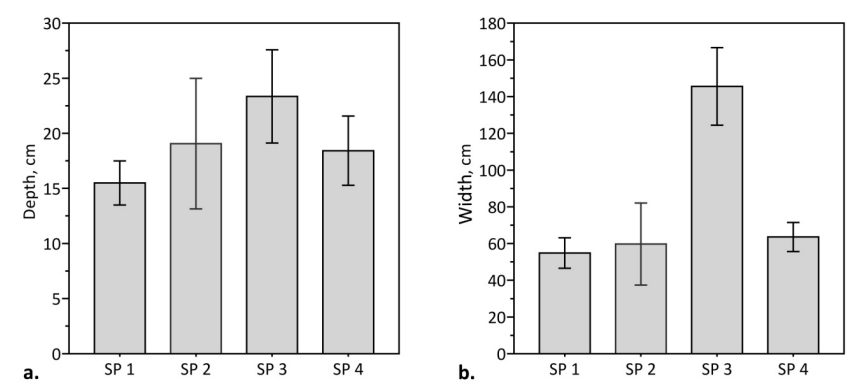

Fig 3. Depth (a) and width (b) of tracks formed at the beginning of the experiment after 180 passes (SP №1, SP №2, SP №3) or 110 passes (SP №4) in the Polistovsky State Nature Reserve during 2016-2018. 
The plant community of Phragmites-Sphagnum mesotrophic bog site is the least resistant (SP №3): here the widest and deepest paths are formed. After 60 passes, the track width was 1.6 times $(\mathrm{t}=4.17$; $\left.\mathrm{t}_{(0.05)}=2.45\right)$ higher than the width of track in the shrub-Carex-Sphagnum plant community (SP №1) under the same load, while after 180 passes, it was 2.7 times $\left(\mathrm{t}=10.6 ; \mathrm{t}_{(0.05)}=2.45\right)$ higher. Complete destruction of vegetation cover was observed even after 60 passes. The width of such a path was $70.3 \pm$ $5.6 \mathrm{~cm}$, the depth was $20.4 \pm 2.4 \mathrm{~cm}$.

Certain vegetation types are capable to resist damage as long as trampling intensity does not exceed a threshold of vulnerability. After that, the damage increases as the trampling intensity increases (Cole, 1995a). It is reasonable for meadow and forest ground vegetation type where the damage was estimated as a vegetation cover change. In the investigated bog sites, the vegetation cover was mostly presented by a continuous Sphagnum mat (80-100\%) with minor participation of vascular plants. In this case, the fragmentation and complete destruction of the Sphagnum mat should be regarded as an exceeding of a threshold. The number of passes, after which the destruction of the plant cover occurred, was different in each bog plant community by corresponding to the maximum load capacity threshold. The lowest threshold was determined for the Phragmites-Sphagnum mesotrophic site at 60 passes, corresponding to visits by one person twice a day during a month. A higher threshold has been defined in the shrub-Carex-Sphagnum mesotrophic bog in SP №4 at 90 passes. SP №1 and SP №2 have the highest threshold at 180 passes.

\section{Vegetation cover regeneration}

By studying the vegetation cover regeneration after trampling impact, Botch (1981) concluded
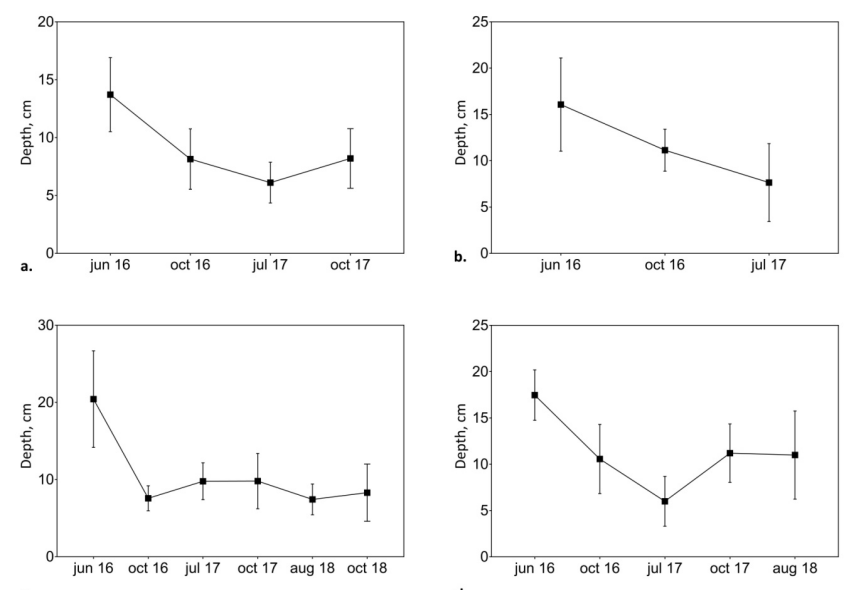

Fig 4. Dynamics of the bog vegetation recovery after 60 passes (SP №1 (a), SP №2 (b), SP №3 (c)) and after 70 passes (SP №4 (d)) in the Polistovsky State Nature Reserve during 2016-2018. that the moderately moist Sphagnum plant communities recover quickly and demonstrate little damage, due to the absolute dominance by Sphagnum mosses with medium turf density that have a fast linear increase (3-4 cm per year). The most hydrophilic Sphagnum communities have loose turf, which could be easily destroyed. But due to the large (7-8 cm per year) linear growth of Sphagnum, it recovers rapidly. Thus, the rate of bog vegetation cover resilience depends on a number of factors: the groundwater level, Sphagnum species composition, and density of Sphagnum shoots. Wet sites with a dense cover of fast-growing species would have the greatest potential for recovery. However, the same parameters, except the density of the turf, have an inverse relationship with resistance to damage. Consequently, with equal trampling loads, the faster recovery will occur in bog plant communities having average values of moisture and Sphagnum cover density.

Repeated measurements of paths in the summer and autumn of 2017-2018 gave us an idea of the recovering of the trampled areas in the absence of other anthropogenic impacts (Fig. 4, Fig. 5). By the autumn of 2018, the tracks in SP №2 and SP №4 with maximum loads, 180 and 110 passes respectively, had recovered completely. And the paths with a smaller number of passes had recovered even earlier, i.e. in the summer of the same year. In SP №1, the rate of recovery was comparable to SP №4 in 2017. Unfortunately, in 2018 we could not complete the recovery description in SP №1 because it became a part of the bogshoe walking route. In SP №3 the paths with a load of 1, 4, 6 and 20 passes were also overgrown by summer. But the tracks with a load of 60 and 180 passes did not recover even by autumn.
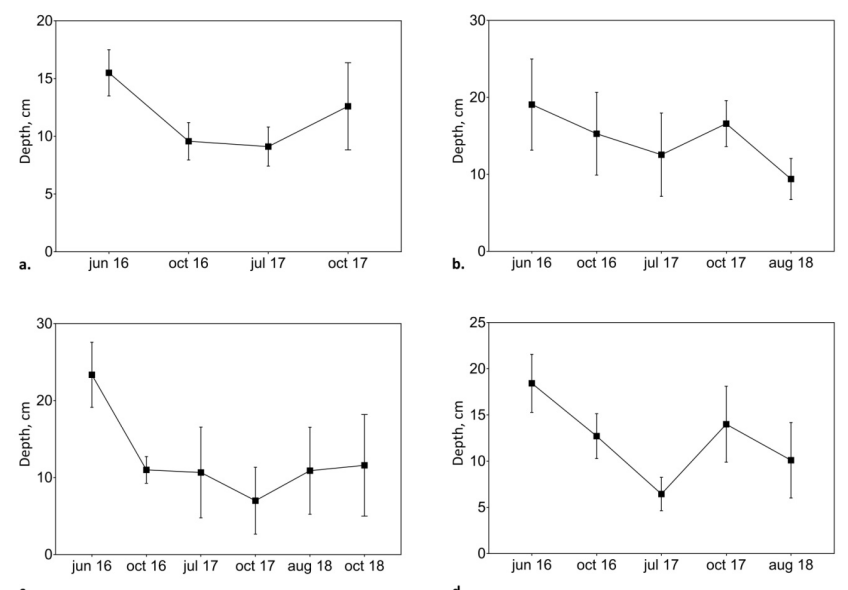

Fig 5. Dynamics of the bog vegetation recovery after 180 passes (SP №1 (a), SP №2 (b), SP №3 (c)) and after110 passes (SP №4 (d)) in the Polistovsky State Nature Reserve during 2016-2018. 
Comparing the depth and width of the tracks at the beginning (in 2016) and the end (in 2018 autumn) of the experiment, we found different rates of vegetation cover resilience. According to 2016 data, the mesotrophic shrub-Carex-Sphagnum bog demonstrated the highest recovery in SP №1. However, during the following years, the rates of vegetation cover recovery decreased. As a result, the community in SP №1 had a moderate resilience ability. The tracks in SP №2 (oligotrophic Eriophorum-Sphagnum plant community) and SP №4 (mesotrophic shrub-Carex-Sphagnum plant community) were overgrown completely by autumn 2018. The Phragmites-Sphagnum plant community on the mesotrophic bog site (SP №3) demonstrated the lowest resilience. However, there were some interesting findings. If we compare the summer and autumn width and the depth of the tracks in each SP, then it can be noted that the tracks did not recover during the summer, but they were slightly «blurred» by autumn. Botch (1981) stated that the paths trampled during the autumn are recovering worse than the paths trampled during the spring. However, this study did not contain data on changes of the parameters during the entire season. By comparing the data for all the years, it can be seen that the expansion of the tracks by the autumn was most clearly visible in 2017, when in the bogs the water level was quite high during the summer.

\section{Tolerance of wetland plant communities}

The vegetation ability to tolerate recurrent trampling depends on its ability to self-recovery more than its ability to resist when damaged (Cole, 1995a). We compared all our sample plots by identifying the bog plant communities with the highest and lowest resistance to trampling and resilience after treatment. Then, we arranged them below in descending order of tolerance to trampling.

SP №2. According to the results of our three-year monitoring, the oligotrophic Eriophorum-Sphagnum bog with pine (Pinus sylvestris (f. willkomii) - Andromeda polifolia + Oxycoccus palustris + Eriophorum vaginatum + Rhynchospora alba - Sphagnum magellanicum) was the most tolerant to trampling due to the relatively moderate resistance and resilience abilities, despite its recovery in the first study year, slower than in the other studied plant communities.

SP №1. The mesotrophic shrub-Carex-Sphagnum bog (Chamaedaphne calyculata + Oxycoccus palustris + Menyanthes trifoliata + Eriophorum vaginatum - Sphagnum fallax) was the most resistant to trampling of the vegetation cover. However, it was in- ferior to the plant community in SP №2 in resilience ability, and, as a result, less tolerant to trampling.

SP №4. The mesotrophic shrub-Carex-Sphagnum bog (Betula pendula - Andromeda polifolia + Menyanthes trifoliata + Eriophorum vaginatum - Sphagnum magellanicum + Sphagnum fallax) was sufficiently resistant to trampling. However, this did not compensate for the less rate of resilience, which was inferior to SP №1 and SP №2.

SP №3. The mesotrophic Phragmites-Sphagnum bog (Pinus sylvestris (f. willkomii) - Chamaedaphne calyculata + Phragmites australis + Eriophorum vaginatum - Sphagnum fallax + Polytrichum strictum) demonstrated the least resistance to pressure and the least ability to resilience in comparison to the other sample plots. After the complete destruction of the vegetation cover after 60 and 180 passes, the plant community remained destroyed by autumn 2018 at the path with a load of 180 passes, despite a slight decrease in the depth and width.

\section{Conclusions}

Wetland vegetation cover vulnerability to human trampling damage varies for different bog plant communities and depends primarily on the composition of the Sphagnum vegetation cover and moisture conditions. With an increasing water content on the site, its resistance decreases. According to the obtained results, the Phragmites-Sphagnum community (SP №3) was the least resistant to the trampling impact, while the shrub-Carex-Sphagnum community (SP №1) was the most resistant. The maximum permissible loads (thresholds) in these bog plant communities were determined at a point beyond which an excess load would lead to the complete destruction of the vegetation cover. We found that the Phragmites-Sphagnum mesotrophic bog site is destroyed the quickest (load threshold is 60 passes). The shrub-Carex-Sphagnum community of a mesotrophic bog and Pinus-Eriophorum-Sphagnum community of an oligotrophic bog are more resistant (load threshold is about 180 passes).

By determining the recreational sustainability of wetland plant communities, it is also necessary to take into account their ability to recover after damage (resilience). In the studied plots, the tracks with low load ( 1 and 4 passes) overgrown completely during the 2016 summer period (June-October), while the tracks with heavy load (6-180 passes) had different degrees of recovery. The Pinus-Eriophorum-Sphagnum community of the oligotrophic bog (SP №2) had the highest resilience in the long-term. Its vegetation cover was 
the most tolerant and by the late 2018 , it had recovered completely. The shrub-Carex-Sphagnum communities in SP №1 and SP №4 demonstrated higher recovery rates with a higher resistance in the first year. At the same time, in the long-term perspective, they were inferior in the resilience ability to the Pinus-Eriophorum-Sphagnum vegetation cover in SP №2 and as a result, SP №1 and SP №4 turned out less tolerant to the trampling than SP №2. In the trampled tracks of the Phragmites-Sphagnum mesotrophic bog (SP №3), the plant community did not recover after three study years with a load of 60 and 180 passes. Such a weak ability to resilience and low resistance to damage suggests that this plant community has the least tolerance for trampling.

Thus, before planning tourist and recreational routes through wetlands, we recommend take into account the heterogeneity of wetland plant communities and the differences in the degree of their tolerance for trampling.

\section{Acknowledgements}

The research was supported by the financial and technical assistance of the Polistovsky State Nature Reserve. The authors are grateful to S.Y. Igosheva (Head of the Department for Science of the Polistovsky State Nature Reserve), as well as to all the inspectors for supporting us on the routes.

\section{References}

Botch M.S. 1981. Effect of recreational trampling on peat bog's vegetation (on the example of string bog the Leningrad region). In: VI All-Union conference "Humaninduced changes, conservation of vegetation in wetlands and adjacent areas». Minsk: Nauka i technika. P. 108-113. [In Russian]

Botch M.S., Masing V.V. 1979. Mire ecosystems in the USSR. Leningrad: Nauka. 188 p. [In Russian]

Chizhova V.P. 2011. Recreational landscapes: resilience, regulation, management. Smolensk: Ecumene. 176 p. [In Russian]

Cole D.N. 1995a. Experimental trampling of vegetation. I. Relationship between trampling intensity and vegetation response. Journal of Applied Ecology 32(1): 203 214. DOI: $10.2307 / 2404429$

Cole D.N. 1995b. Experimental trampling of vegetation. II. Predictors of resistance and resilience. Journal of Applied Ecology 32(1): 215-224. DOI: 10.2307/2404430

Cole D.N. 1995c. Recreational Trampling Experiments: Effects of Trampler Weight and Shoe Type. Research paper INT. Department of Agriculture Forest Service. United States 425(8): 1-4. DOI: 10.2737/INT-RN-425

Hammitt W.E., Cole D.N., Monz C.A. 2015. Wildland Recreation: Ecology and Management. $3^{\text {rd }}$ edition. Hoboken: Wiley Blackwell. 334 p.
Hassel K., Kyrkjeeide M., Yousefi N., Presto T., Stenoien H., Show A., Flatberg K.I. 2018. Sphagnum divinum (sp. nov.) and $S$. medium Limpr. and their relationship to $S$. magellanicum Brid. Journal of Bryology 40(18): $197-$ 222. DOI: $10.1080 / 03736687.2018 .1474424$

Korolkova E.O., Shkurko A.V. 2016a. The ecological routes on the mire ecosystems of protected areas of the European Russia educational potential. Biology at School 4: 72-80. [In Russian]

Korolkova E.O., Shkurko A.V. 2016b. The sustainability of bog plant communities of the Polistovsky nature reserve for the recreation impact. Environment and $\mathrm{Hu}$ man: Ecological Studies 4: 50-77. [In Russian]

Korolkova E.O., Shkurko A.V. 2017. The recreation sustainability of bog plant communities of the Polistovsky nature reserve. In: VIII meeting in memoriam of Ekaterina Alexeevna Galkina. Saint-Petersburg. P. 53-55.

Korolkova E.O., Shkurko A.V. 2019. Valuation of the impacts of recreation on plant communities of mires. In: $X$ meeting in memoriam of Ekaterina Alexeevna Galkina. Saint-Petersburg. P. 100-102.

Korolkova E.O., Zueva N.V., Arkhipov V.Yu., Shkurko A.V., Anissimova A.G. 2017. Features of ecological tourism in wetland ecosystems on of the Rdeysky nature reserve example. Environment and Human: Ecological Studies 4: 78-93. [In Russian]

Kose M., Tammiste D.E. 2018. Bog tourism in Estonia: how to measure the impact of bogshoeing? In: IX meeting in memoriam of Ekaterina Alexeevna Galkina. SaintPetersburg. P. 97-98.

Marzano M., Dandy N. 2012. Recreational use of forests and disturbance of wildlife - a literature review. Edinburgh: Forestry Commission. 40 p.

Mironov V.L., Kondratyev A.Y. 2017. Peat moss Sphagnum riparium follows a circatrigintan growth rhythm in situ: a case report. Chronobiology International 34(7): 981984. DOI: 10.1080/07420528.2017.1329208

Mironov V., Kondratyev A., Shkurko A. 2018. Growth of Sphagnum riparium is strongly rhythmic: contribution of the seasonal, circalunar and third rhythmic components. BioRxiv. DOI: 10.1101/415539

Nature of Polistovsky Reserve. In: Web-site of the Polistovsky State Nature Reserve. 2019. Available from: http://polistovsky.ru/en/nature

Pickering C., Rossi D. A., Hernando A., Barros A. 2018. Current knowledge and future research directions for the monitoring and management of visitors in recreational and protected areas. Journal of Outdoor Recreation and Tourism 21: 10-18. DOI: 10.1016/j.jort.2017.11.002

Sirin A.A., Minayeva T.Y. 2001. Peat bogs of Russia: to the analysis of industry information. Moscow: Geos. 190 p. [In Russian]

Slater F.M., Agnew A.D. 1977. Observations on a peat bog's ability to withstand increasing public pressure. Biological Conservation 11(1): 21-27. DOI: 10.1016/00063207(77)90023-4

Zelenkevich N.A., Grummo D.G., Sozinov O.V. 2008. The impact of recreational pressure on vegetation of sphagnum bogs. Botany: research 35: 45-53. [In Russian] 


\title{
РЕКРЕАЦИОННАЯ УСТОЙЧИВОСТЬ БОЛОТНЫХ ФИТОЦЕНОЗОВ ПОЛИСТОВСКОГО ЗАПОВЕДНИКА (РОССИЯ)
}

\author{
Е. О. Королькова ${ }^{1,2}$, А. В. Миронова ${ }^{3}$ \\ ${ }^{1}$ Национальный исследовательский университет Высшая школа экономики, Россия \\ ${ }^{2}$ Московский педагогический государственньй университет, Россия \\ e-mail:korol-k@mail.ru \\ ${ }^{3}$ Институт биологии Карельского научного иентра РАН, Россия \\ e-mail:shen-ku@bk.ru
}

\begin{abstract}
С развитием в России такого вида экологического туризма, как путешествие по охраняемым болотам, определение рекреационной устойчивости данных территорий становится актуальной задачей. Цель нашего исследования - оценка влияния рекреационного природопользования на болотные фитоценозы экологической тропы «Плавницкое болото» в Полистовском заповеднике путем решения следующих задач: 1) определить порог допустимой антропогенной нагрузки на участках болота с различными типами растительных сообществ; 2) оценить восстановление фитоценозов, 3) выявить относительную устойчивость различных фитоценозов. Моделирование прямого антропогенного воздействия на болотные фитоценозы с различной величиной нагрузки позволило наглядно оценить повреждения фитоценоза и выявить их устойчивость и последующую способность к самовосстановлению. По результатам наших исследований наименее устойчивым к механическому воздействию оказался фитоценоз переходного тростниково-сфагнового болота без древесного яруса (Pinus sylvestris (f. willkomii) - Chamaedaphne calyculata + Phragmites australis + Eriophorum vaginatum - Sphagnum fallax + Polytrichum strictum), a наиболее устойчивым - фитоценоз переходного болота без древесного яруса кустарничково-осоковосфагнового (Chamaedaphne calyculata + Oxycoccus palustris + Menyanthes trifoliata + Eriophorum vaginatum - Sphagnum fallax). После снятия антропогенной нагрузки на исследуемых участках поврежденный растительный покров восстановился в разной степени. В первый год быстрее всего восстановились сообщества кустарниково-осоково-сфагнового болота, где в условиях мезотрофного питания и плотного стояния грунтовых вод преобладают относительно гидрофильные виды сфагновых мхов. По результатам трёхлетних наблюдений верховое структурированное болото пушицево-сфагновое с сосной на кочках (Pinus sylvestris (f. willkomii) - Andromeda polifolia + Oxycoccus palustris + Eriophorum vaginatum + Rhynchospora alba - Sphagnum magellanicum) оказалось наиболее устойчивым, так как восстанавливается быстрее остальных. На некоторых участках тростниково-сфагнового переходного болота без древесного яруса первоначальный фитоценоз через три года не восстановился; таким образом, этот тип болота является наиболее уязвимым к рекреационному воздействию.
\end{abstract}

Ключевые слова: антропогенное воздействие, водно-болотные угодья, ООПТ, рекреация, экологический туризм 